\title{
TRENDS RESEARCH OF THE INFORMATION ECONOMY BASED ON GLOBAL INTERNATIONAL INDICES
}

\section{ДОСЛІДЖЕННЯ ТЕНДЕНЦІЙ РОЗВИТКУ \\ ІНФОРМАЦІЙНОЇ ЕКОНОМІКИ \\ ЗА ГЛОБАЛЬНИМИ МІЖНАРОДНИМИ ІНДЕКСАМИ}

\author{
Nadiia Morozova ${ }^{1}$ \\ Tetyana Novikova ${ }^{2}$ \\ Timur Malafeyev ${ }^{3}$
}

DOI: https://doi.org/10.30525/978-9934-26-049-0-8

Abstract. The article describes the uneven development of the information economy based on an analysis of the ICT development index in order to identify innovative growth at the national, regional, and global levels. The aim of the work is to develop a set of models for the analysis of the dynamics of the information economy, which makes it possible to determine the stages of the information economy development, groups of countries according to the level of ICT development, and to assess the factors impact of ICT development on the economic growth rate. The work considered the set of information indicators for assessing the level of the information economy development and analyzed development trends of the information economy by macro-region; developed a country profile model for ICT development and built a model for measuring the impact of ICT development on economic growth.

Special empirical measures - international indices - are used to determine the extent of the impact of informatization on the countries' development. All the indicators used in the work form the basis of the Information and Communication Technology (ICT) Development Index. This suggests that the ICT index is a universal tool for comparing world economies.

\footnotetext{
${ }^{1}$ Candidate of Economic Sciences, Associate Professor,

V.N. Karazin Kharkiv National University, Ukraine

${ }^{2}$ Candidate of Economic Sciences, Associate Professor,

V.N. Karazin Kharkiv National University, Ukraine

${ }^{3}$ Candidate of Science in Public Administration, Associate Professor,

V.N. Karazin Kharkiv National University, Ukraine
}

(C) Nadiia Morozova, Tetyana Novikova, Timur Malafeyev 
Research has been carried out based on neural network modelling techniques, in particular the Kohonen network and econometric methods and models.

The article discusses the use of ICT to analyze the information economy at the macroeconomic level to measure the impact of ICT on the gross national product. The author's concept of research on the impact of ICT on the gross national product of the countries of the world has been developed. The author's concept scheme consists of two blocks. The first block consists of the construction of country groupings based on the level of ICT development. Based on the Kohonen networks, the countries have been clustered according to the level of development of information and communication technologies, which will make it possible to compare the world economies and to highlight priority and problem areas in the implementation of ICT. The second block is to study the influence level of the ICT development index on countries' GDP using econometric models of macroeconomic indicators.

The relationship between ICT and GDP has been confirmed. The simulation found that the potential for increasing GDP through ICT was greater for developing countries than for developed countries because for developed countries ICT using was routine and necessary. The impact of further ICT development in developed countries is such that, with an increase of $1 \%$ in ICT use, GDP increases by $0.6 \%$. For developing countries, however, the opposite is true. An increase of $1 \%$ in the rate of ICT increases GDP by $1.2 \%$ on average, i.e., such countries have the potential to develop and meet the targets of developed countries.

The findings and results of the study can be used by policymakers and enterprises to ensure better ICT outcomes, which in turn can promote sustainable economic and social development, both in certain countries and globally.

\section{1. Вступ}

Сучасна динамічна конкуренція, заснована на інноваційному перетворенні економічного простору, посилила роль інформації в процесі суспільного виробництва. Вона стала домінуючим чинником конкурентоспроможності підприємств, галузей, регіонів і країн, створюючи можливості для людського капіталу широко використовувати свій 
потенціал для досягнення взаємодоповнюючих цілей забезпечення стійкого економічного розвитку. Інформація та технології, пов'язані 3 нею, визначають темпи зростання економіки - темпи приросту ВВП, а також ступінь зрілості, розвитку і становлення громадянського суспільства.

Сучасна економіка є багатосекторною: вона включає сектор традиційної індустріальної економіки, сектор традиційної постіндустріальної економіки, сектор інноваційної економіки, сектор інформаційної економіки, венчурний бізнес та інші кластери і сектора нових технологій. Фундаментом, який забезпечує системне функціонування всіх секторів економіки і держави в цілому, виступає інформаційний сектор, який в його сучасному розумінні включає провідні галузі матеріального виробництва, що забезпечують технологічний прогрес, сферу надання послуг комунікації і зв'язку, виробництво інформаційних технологій та програмного забезпечення, а також різні види технічної освіти.

Формування інформаційного сектора економіки тісно пов'язане 3 глобальною інформатизацією економіки, розвитком інформаційного суспільства. Цей процес обумовлює кардинальні зміни у всій економічній системі країни. В рамках інформаційного сектора економіки змінюється значення інститутів, форм їх взаємовідносин, рушійних сил, властивих економічній системі, значення нових факторів виробництва та їх використання. Все більша частка ВВП забезпечується діяльністю 3 виробництва, обробки, зберігання і розповсюдження інформації, знань, що веде до збільшення числа зайнятих цією діяльністю.

Глобалізація і інтенсифікація інформаційних процесів, інформатизація всіх сфер діяльності суспільства, підвищення рівня розвитку інформаційної інфраструктури, необхідність залучення нових технологій у виробничий процес обумовлюють необхідність грунтовного дослідження проблем формування і розвитку інформаційного сектора економіки. Крім того, ця тема є актуальною в умовах інтеграції України в Свропейський союз. Країни $С С$ активно використовують та тримають високі показники розвитку IКТ. Як відомо, країни-члени СС характеризуються високим економічним розвитком. Не останню роль у цьому займає розуміння та активне використання IКТ. Саме тому, на нашу думку, слід звернути більш детальну увагу на дослідження цього важливого і актуального питання. 


\section{2. Аналіз особливостей розвитку та мета дослідження}

Одним з перших авторів, що правильно розпізнає основну особливість інформаційної економіки, був Махлуп (1962р.) [12], який використовував термін «заснована на знаннях галузь», щоб описати іiі. Він виявив, що до 1959 року професії, що виробляють знання, перевищили інші за кількістю. Однак вже в 1973 році такі автори, як Деніел Белл (1973 р.), продовжували посилатися на економіку, що розвивається як «постіндустріальну». У 1977 році Марк Урі Порат (1977р.), до якого пізніше приєднався Рубін, написав 9-томну дисертацію, в якій вимірювався і оцінювався розмір цієї економіки, і описував цей сектор, що розвивається, як «інформаційну економіку». Його робота з тих пір широко цитується як перше загальне використання терміну «інформаційна економіка» [16]. Порат проводить відмінність між двома економічними областями: областю матерії та енергії і областю інформації. Останній він називає інформаційним сектором, а перший - сектором сільського господарства і промисловості. Інформаційний сектор включає в себе перетворення інформації «з одного шаблону в інший». Економіка стає інформаційною економікою, коли пов'язана з інформацією робота починає перевищувати роботу, пов'язану з іншими секторами [17]. Сучасні науковці також приділяють багато уваги дослідженню питань розвитку інформаційної економіки. Питанням впливу ІКТ на розвиток інформаційного суспільства та його інноваційне зростання були присвячені праці таких закордонних та вітчизняних вчених як Д. Белл, О. Виноградова, С. Войтко, Б. Гейтс, О. Гудзь, В. Іванов, П. Друкер, Я. Жаліло, М. Кастельс, О. Карпенко, К. Князев, М. Коннорс, С. В. Легомінова, Й. Масуда, Р. Радзієвська, В. Степанова, Е. Тоффлер, $Ф$. Уебстер та інші. Враховуючи значні наукові результати, отримані на даний момент дослідниками, слід зазначити, що підвищена актуальність даної проблематики породжує виникнення низки нових завдань, вирішення яких потребує подальших досліджень.

Кожна економіка у процесі розвитку ІКТ стикається з різними проблемами, пов'язаними з її географією, потребами в інфраструктурі і соціально-економічною структурою, а також ресурсами, якими вона володіє. Політичні заходи, спрямовані на поліпшення середовища IКТ, повинні бути адаптовані до цих конкретних характеристик. Проте, уряди і підприємства ІКТ можуть використовувати досвід більш дина- 
мічних країн при розробці своїх планів щодо поліпшення національного середовища IКТ. Розуміння того, як і чому деякі країни досягли більш високих темпів розвитку ІКТ, може допомогти директивним органам і підприємствам інших країн в тому, що вони будуть домагатися кращих результатів в сфері IКТ, що, в свою чергу, буде сприяти сталому економічному та соціальному розвитку в їх країнах.

Тому дана стаття присвячена аналізу нерівномірностей розвитку інформаційної економіки на основі аналізу індексу розвитку ІКТ для визначення напрямків інноваційного зростання у національному, регіональному та світовому масштабах. Метою роботи $\epsilon$ розробка комплексу моделей аналізу динаміки інформаційної економіки, який дозволяє визначити стадії розвитку інформаційної економіки, групи країн за рівнем розвитку IКТ; оцінити вплив факторів розвитку ІКТ на темпи економічного зростання. Дослідження проводиться на основі методів нейромережевого моделювання, зокрема, використовуються мережі Кохонена та економетричні методи та моделі $[1 ; 2 ; 6]$.

\section{3. Аналіз індикативного простору показників}

Для визначення ступеня впливу інформатизації на розвиток країн використовуються спеціальні емпіричні вимірювачі - міжнародні індекси. Найбільш показовими є: ISI - Індекс інформаційного суспільства, ERI - Індекс електронної готовності, KEI - Індекс економіки знань, EGDI - Індекс розвитку електронного уряду, DAI - Індекс цифрового доступу, TAI - Індекс технологічних досягнень, NRI - Індекс мережевої готовності, DOI - Індекс цифрових можливостей, ICT OI Індекс можливостей IKT, ICT DI - Індекс поширення IKT, GCI - Індекс глобальної конкурентоспроможності, GII - Індекс глобальних інновацій. Детальніше про формування індексів йдеться у [15].

Усі наведені індикатори складають основу індексу розвитку ІКТ. Це дає можливість зробити припущення, що даний індекс є універсальним інструментом для порівняння світових економік. Тому, надалі, буде розглядатися саме цей індекс. На рис. 1 наведено динаміку IКТ за деякими регіонами світу з 2010 по 2019 рік. Європа є регіоном, який може похвалитися найвищим середнім показником IКТ, який дорівнює 7,55 у 2017 році та зріс до 9,02 у 2019 році. Така динаміка свідчить про те, що всі країни в регіоні характеризуються високими або відносно 
високими показниками ефективності, але існують також деякі географічні відмінності в розподілі. Позиції в верхній частині регіонального рейтингу в основному займають країни Північної і Західної Європі, а в нижній частині - країни Південної та Східної Європи. Як і в попередні роки, п'ять скандинавських країн - Данія, Фінляндія, Ісландія, Норвегія і Швеція - займають особливе місце, всі входять до двадцятки кращих в світі.

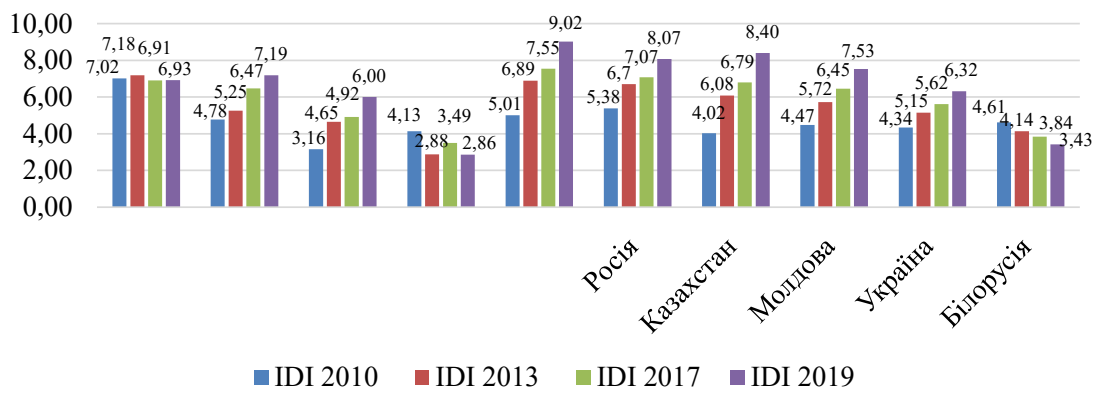

\section{Рис. 1. Динаміка індексу розвитку інформаційно-комунікаційних технологій (ІКТ) по регіонам світу за період 2010-2019}

Джерело: складено автором на основі [11; 13-14]

Так як вектор політики України направлено в бік інтеграції з Свропейським Союзом, слід розглянути як співвідносяться показники України за індексом ІКТ до показників країн СС. На рис. 2. зображено, як відрізняються показники ІКТ України від середніх значень СС. Так, бачимо, що за двома показниками Україна має значення, більше середніх в Євросоюзі. Це відсоток людей, що мають вищу освіту та абоненти мобільного зв'язку. У той же час, за показником підписок мобільного широкосмугового зв'язку спостерігається досить сильне відставання від показників ЄС.

3 наведеного аналізу робимо висновок, що інформаційно-комунікаційні технології мають сильний вплив на економічні результати країни. Тому для інтеграції України в СС слід вжити заходів щодо підвищення ефективності використання IКТ. Досвід країн-членів СС говорить, про позитивний вплив IКТ на динаміку розвитку економіки країни. Дослідження щільності зв'язку між рівнями економічних показників 


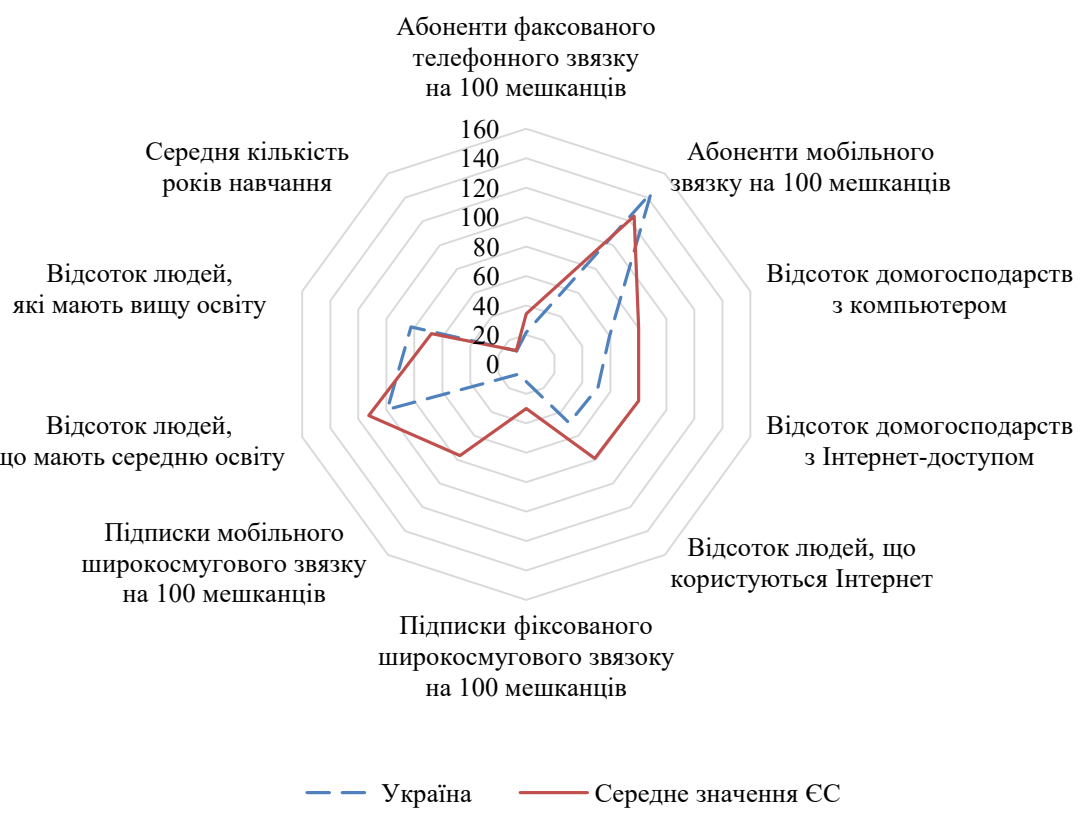

Середня кількість років навчання

160

140

120

100

Відсоток людей, які мають вищу освіту

Відсоток людей, що мають середню освіту

Підписки мобільного широкосмугового звязку на 100 мешканців
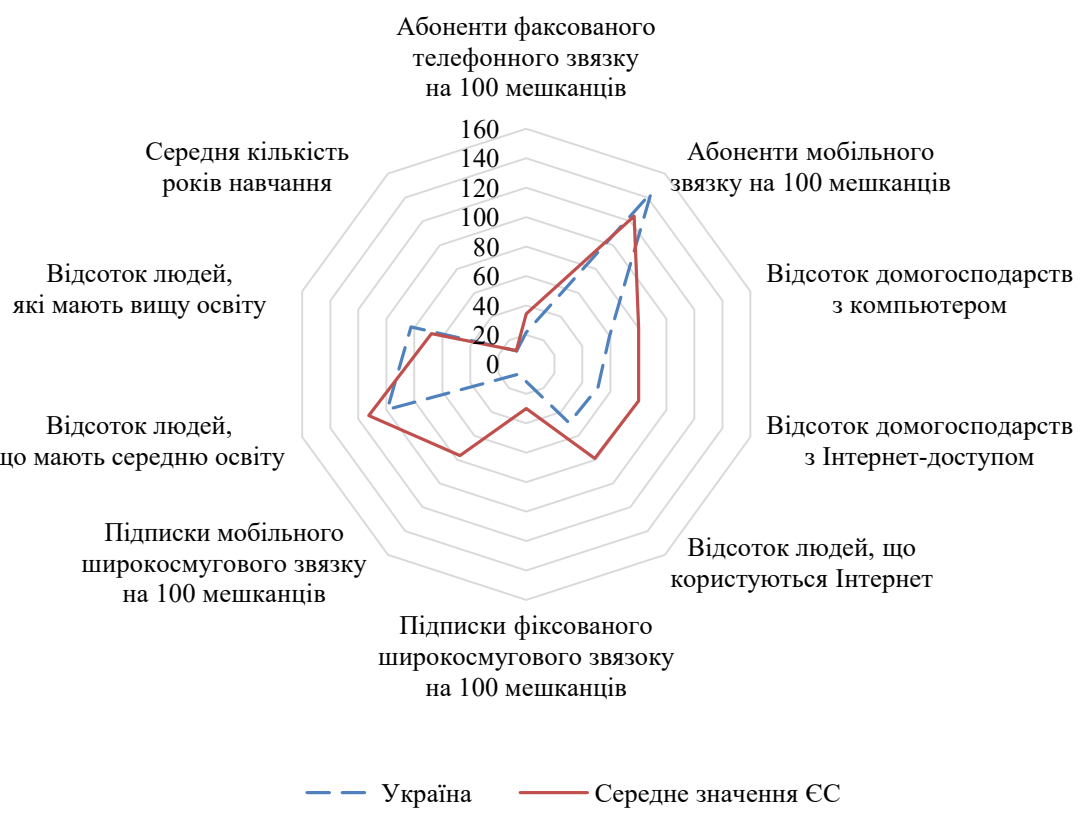

\section{Рис. 2. Порівняння значень індикаторів ІКТ України та країн СС} Джерело: складено автором на основі [11; 13-14]

і рівнями продуктивності ІКТ, що знаходить відображення в варіаціях між різними географічними регіонами та всередині них, і $€$ предметом даного дослідження.

\section{4. Концептуальна схема дослідження IКT}

У статті для аналізу інформаційної економіки буде розглянуто використання IКТ на макроекономічному рівні з метою оцінки впливу IКТ на валовий національний продукт. Запропонована концептуальна схема дослідження наведена на рис. 3.

Як видно з рис. 3, концептуальна схема складається 3 двох блоків. Розглянемо їх більш детально. Перший блок передбачає групування країн за рівнем розвитку ІКТ. За допомогою мереж Кохонена країни будуть кластеризовані за рівнем розвитку інформаційно-комунікаційних технологій, що дозволить порівняти світові економіки, виділити 


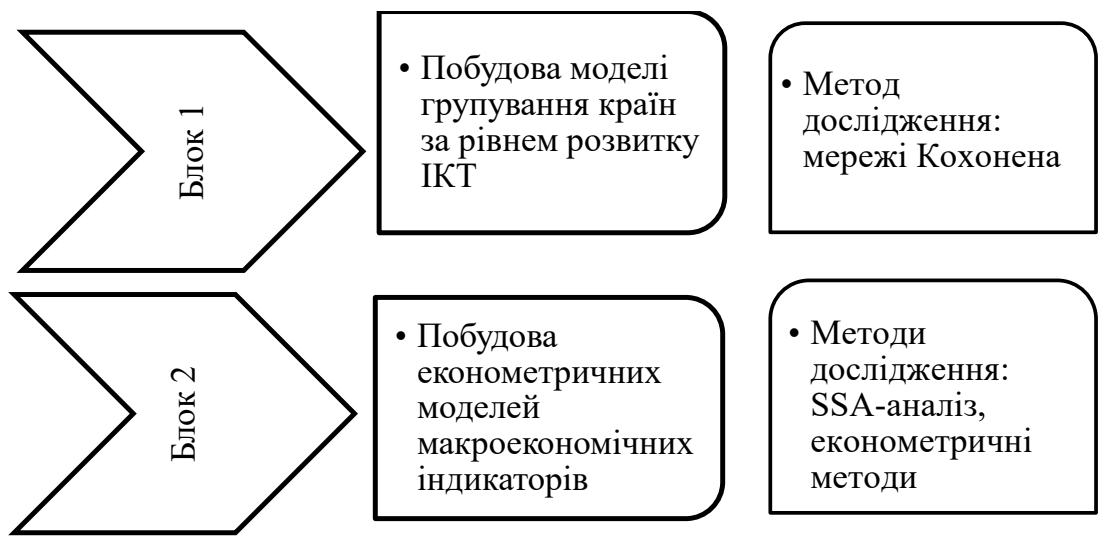

Рис. 3. Концептуальна схема дослідження впливу IКТ на валовий національний продукт країн світу

Джерело: власна розробка авторів

пріоритетні та проблемні області у впровадженні ІКТ. Другий блок передбачає дослідження щільності впливу індексу розвитку ІКТ на рівень ВВП країн з використанням економетричних моделей макроекономічних індикаторів.

\section{5. Моделі групування країн}

Відповідно до запропонованої на рис. 3 концептуальної схеми на першому етапі дослідження здійснюється побудова моделі групування країн за рівнем розвитку ІКТ за допомогою мереж Кохонена [18]. Вихідними даними для побудови моделі є статистичні дані країн за показником ІКТ за 2010-2019 pp. [8-9]. Метою застосування даного інструменту є здійснення кластеризації, тобто виділення однорідних груп країн на основі показника IКТ. Для вирішення завдання будемо використовувати ППП Deductor [4]. На початку роботи запускаємо майстер обробки і вибираємо зі списку метод обробки «Карта Кохонена». Далі слід налаштувати призначення стовпців, тобто для кожного стовпця вибрати одне з призначень: вхідний, вихідний, не використовується і інформаційний. Зазначимо до всіх стовпців, що відповідають динаміці індексу IКТ, призначення «Вхідний». Наступним кроком $є$ 
розбиття вихідної множини на навчальну, тестову та валідаційну. За замовчуванням, програма пропонує розбити множину на навчальну 95\% та тестову - 5\%. Можливі два варіанти кластеризації: автоматичне визначення числа кластерів з відповідним рівнем значущості і фіксована кількість кластерів (визначається користувачем). Оскільки нам невідома кількість кластерів, обираємо автоматичне визначення їх кількості. Запускаємо процес навчання мережі - необхідно натиснути на кнопку «Пуск» і дочекатися закінчення процесу навчання. Під час навчання можемо спостерігати зміну кількості розпізнаних прикладів і поточні значення помилок. Після закінчення навчання налаштовується відображення кластерів. На рис. 4 зображено карти входів. Чітко видно збільшення області, де знаходяться країни з високим і середнім рівнем IКТ та зменшення з низьким показником IКТ.

На першій карті найбільші значення мають об'єкти, розташовані в правому нижньому кутку. Розглядаючи одночасно всі карти, ми можемо сказати, що ці ж об' єкти мають найбільші значення показника на всіх 10 картах.

На рис. 5 наведена ілюстрація матриць відстаней і щільності влучень, а також карта кластерів. Тут ми бачимо сформовані кластери, кожен з яких виділено окремим кольором.

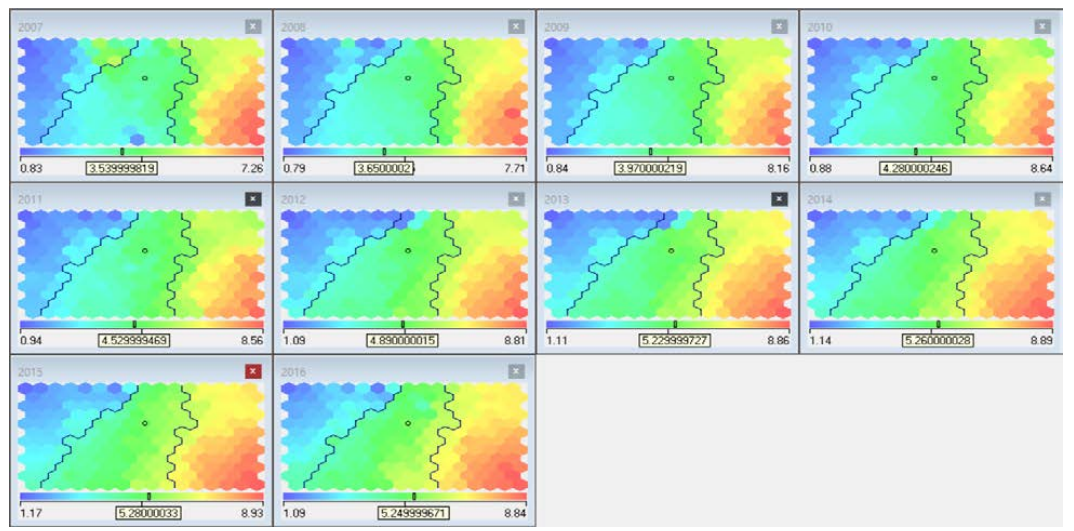

Рис. 4. Карти входів після закінчення навчання за методом обробки «Карта Кохонена»

Джерело: власні розрахунки в ППП Deductor 


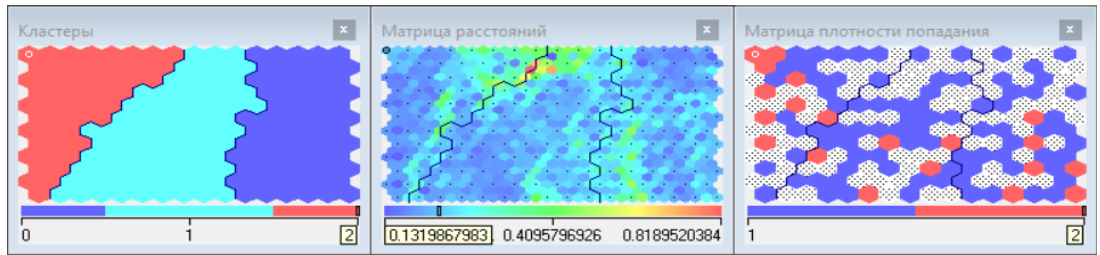

Рис. 5. Кластери, матриця відстаней та щільності влучень Джерело: власні розрахунки в ППП Deductor

Положення України на карті кластерів представлено на рис. 6. Таким чином, Україна входить в кластер із середнім рівнем розвитку ІКТ.

В результаті застосування самоорганізованих карт багатовимірний простір вхідних факторів було представлено в двомірному вигляді, в якому його досить зручно аналізувати. Країни були класифіковані на 3 групи, виходячи з розмальовки показника за різні періоди, можна зробити висновок, про те, що нульовий характеризує країни з низьким рівнем розвитку IКТ, 1-й - із середнім, 2-й - з високим.

Далі слід дослідити, що саме впливає на потрапляння країни в певний кластер в залежності від рівня розвитку IКТ. Тому, слід розглянути кластеризацію за субіндексами доступу, використання і навичок IКТ.
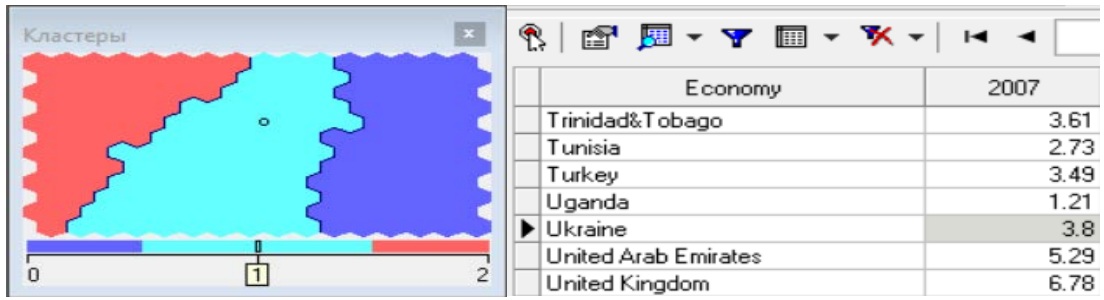

\begin{tabular}{|r|r|r|r|}
\hline Номер ячейки & Расстояние до центра ячейки & Номер кластера & Расстояние до центра кластера \\
\hline 41 & $1.38359541779549 \mathrm{E}-7$ & 1 & 0.2700601019306 \\
\hline 150 & $1.41888358943 \mathrm{E}-7$ & 1 & 0.167701097998584 \\
\hline 46 & $9.02343552978666 \mathrm{E}-8$ & 1 & 0.225868314447478 \\
\hline 72 & 0.0292138812837799 & 2 & 0.235517813412171 \\
\hline 15 & 0.0636016473399046 & 1 & 0.168199399736169 \\
\hline 190 & $2.04761969306878 \mathrm{E}-13$ & 0 & 0.226344685656493 \\
\hline
\end{tabular}

\section{Рис. 6. Визначення положення України на карті кластерів}

Джерело: власні розрахунки в ППП Deductor 
Імпортуємо дані в аналітичне середовище і повторюємо алгоритм, описаний раніше. Після навчання мережі отримуємо результат, представлений на рис. 7.

Аналізуючи карти входів, можна помітити схожість в розфарбуванні першої і другої карт, це говорить про наявність взаємозв'язку між цими показниками. Розглянемо нульовий кластер. Даний кластер характеризується високими значеннями показників. Це дозволяє охарактеризувати даний кластер таким чином - це країни з високим рівнем субіндексів доступу, використання і навичок IКТ. Україна потрапила в кластер, який характеризується середнім рівнем розвитку показників доступу, використання і навичок IКТ. На карті показника навичок IКТ Україна знаходиться в правому верхньому куті. Тут накопичені країни з найбільшими показниками даного субіндексу, про що говорить забарвлення карти (рис. 8).

У той же час, за показниками доступу і використання IКТ Україна належить до групи країн із середніми значеннями. При чому значення показника доступ трохи вище, ніж значення показника використання. Можна зробити висновок, що в цілому інформаційно-комунікаційні технології в Україні розвинуті досить добре. Найбільшим чином на це впливає рівень навичок населення. Але слід розвивати інфраструктуру доступу та використання IКТ.

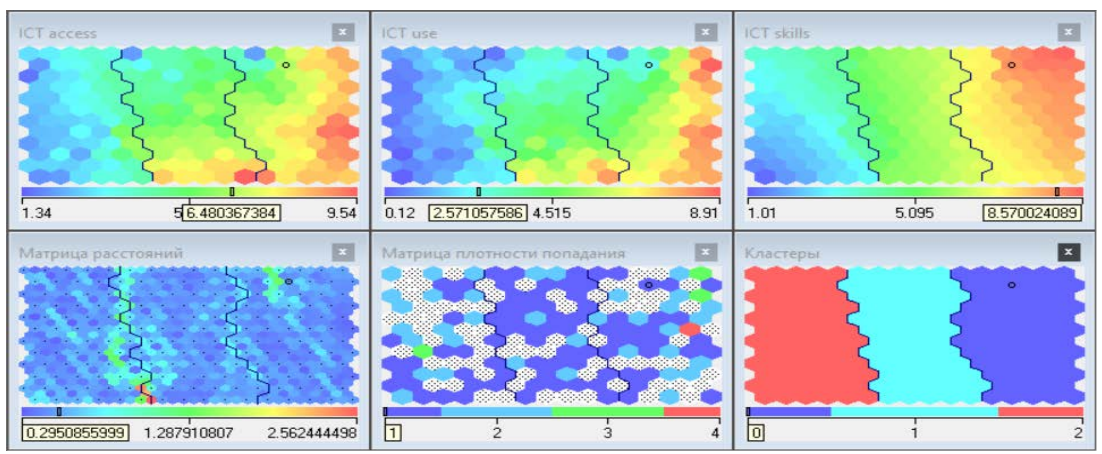

Рис. 7. Результат роботи мережі Кохонена за субіндексами доступу, використання і навичок IKT

Джерело: власні розрахунки в ППП Deductor 


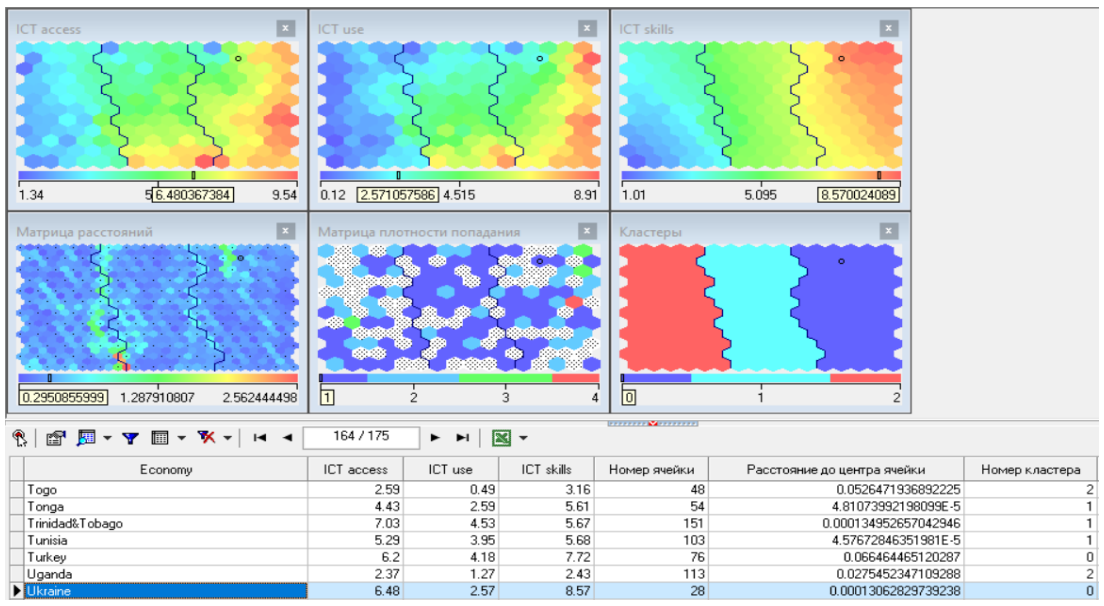

Рис. 8. Розташування України на карті кластерів за субіндексами доступу, використання і навичок IКT

Джерело: власні розрахунки в ППП Deductor

\section{6. Моделі макроекономічних індикаторів}

Відповідно до концептуальної моделі дослідження, наступним кроком $є$ аналіз впливу індексу розвитку IКТ на динаміку макроекономічних показників, зокрема ВВП країн світу.

Для аналізу залежності були обрані значення ВВП в розрахунку на одну особу і значення індексу ІКТ за 2019 рік [8]. Задаємо залежні і незалежні змінні, в даному випадку залежна ВВП, незалежна ІКТ. Аналіз здійснюється у пакеті Statistica. Усі результати аналізу зведено до таблиць 1-3.

Спочатку перевіримо гіпотезу про існування лінійного зв'язку між показниками. Побудуємо лінійну економетричну модель і визначимо найважливіші характеристики моделі і ступінь іiі адекватності. 3 таблиці 1 (стовпець 2) бачимо, що показники ВВП та ІКТ мають високий рівень кореляції (більше 0.7). Для перевірки гіпотези про нормальність розподілу похибок необхідно побудувати їх розподіл на нормальному імовірнісному папері (Normal plot of residuals). 3 побудованого графіка (табл. 1, стовп. 3-4) видно, що розподіл помилок не відповідає кривій нормального закону. Результати зіставлення фактичних та теоретичних значень ВВП наведені на рис. 9. 


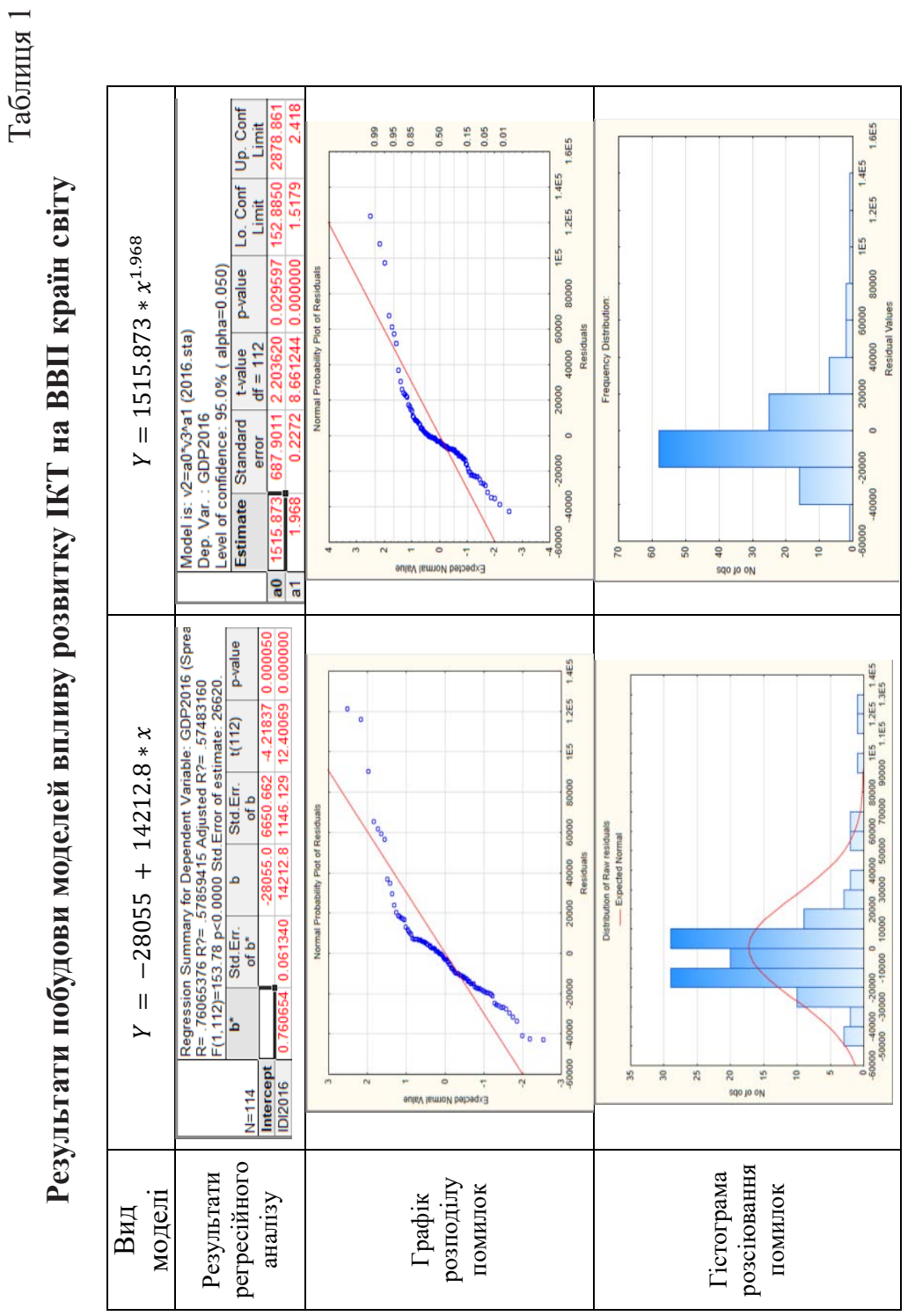

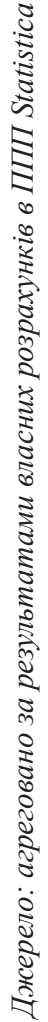




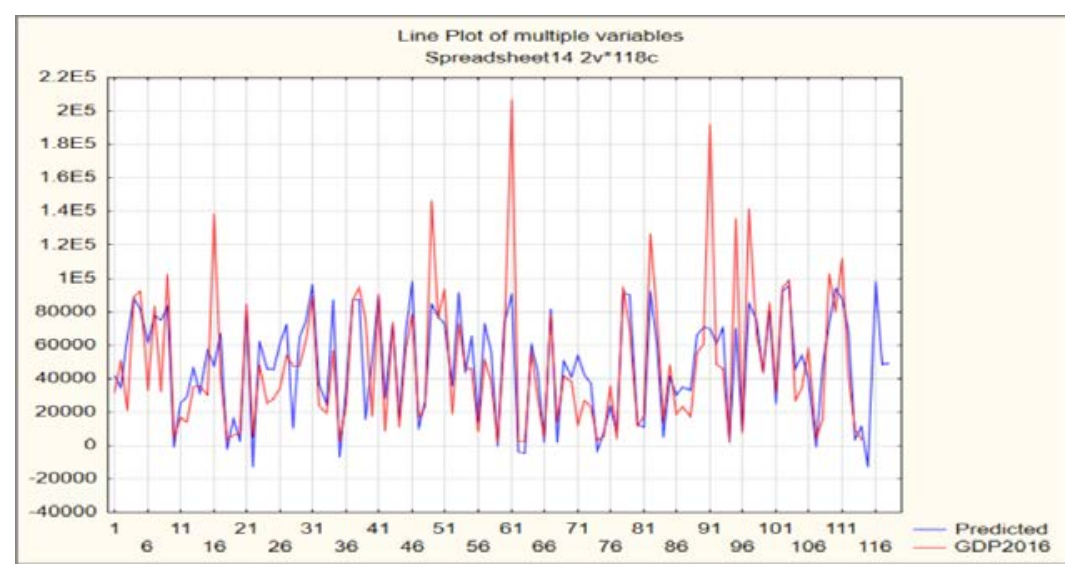

\section{Рис. 9. Зіставлення фактичних та теоретичних значень лінійної функції}

Джерело: власні розрахунки в ППП Statistica

Результати лінійної регресії вказують на наявність лінійного зв'язку між ВВП та індексом ІКТ, але цей зв'язок доволі слабкий.

Тому слід перевірити гіпотезу про існування нелінійного зв'язку між ВВП та індексом ІКТ шляхом побудови степеневої функції і проведемо аналіз адекватності нелінійної економетричної моделі (рядок 2 табл. 1). Оцінки параметрів моделі зображено у стовпці 2. Як бачимо, параметри моделі статистично значущі за критерієм статистики Стьюдента. У таблиці дисперсійного аналізу наведені сума квадратів відхилень по регресії (Sums of Squares Regress), сума квадратів помилок моделі (Sums of Squares Residual), дисперсія помилок (Mean Squares Residual) і критерій Фішера (F - value), що підтверджують високу якість побудованої залежності.

Знаходимо теоретичні значення моделі та порівнюємо їх з фактичними (рис. 10).

Всебічний аналіз помилок моделі можна отримати в опціях Residuals (Похибки). Гістограма помилок і графік розподілу помилок на нормальному імовірнісному папері наведені у стовпцях 3-4 рядка 2 табл. 1. 3 графіків видно, що помилки розподілені за нормальним законом. Отже, можна зробити висновок, що степенева функція краще описує залежність між показником ВВП та ІКТ. Параметр а1 в регре- 


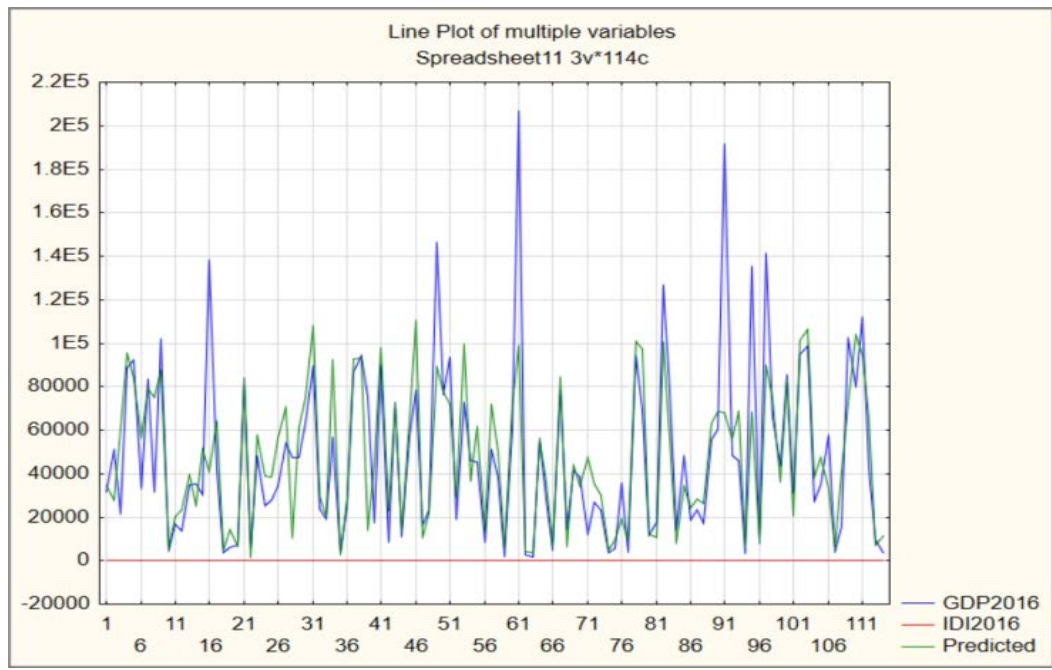

Рис. 10. Зіставлення теоретичних та фактичних значень ВВП для степеневої функції

Джерело: власні розрахунки в ППП Statistica

сійній моделі відображає еластичність ІКТ відносно ВВП. Тому при збільшенні ІКТ на 1\% темп приросту ВВП складе 1.97\%. Це підтверджує гіпотезу про необхідність розвивати інформаційно-комунікаційні технології та створювати умови для їх впровадження.

Розглянемо, як впливає ІКТ на показник ВВП в залежності від рівня розвитку країни. Для початку потрібно визначити рівень розвитку кожної з країн. Для цього вибірка розбивається на інтервали по показнику ВВП на одного жителя. Таким чином можна побачити, в яку групу входить кожна з країн (країни, що розвиваються, розвинені країни або країни з перехідною економікою).

Дослідимо кожен з інтервалів окремо. Зауважимо, що за показником ВВП на особу Україна потрапила до першого інтервалу (з низькими показниками). За описаним вище алгоритмом досліджуємо кожен з інтервалів на наявність лінійного та нелінійного зв'язку між показниками ВВП на особу та індексом розвитку ІКТ. Результати побудови моделей зведемо у таблицю 2. 
Nadiia Morozova, Tetyana Novikova, Timur Malafeyev

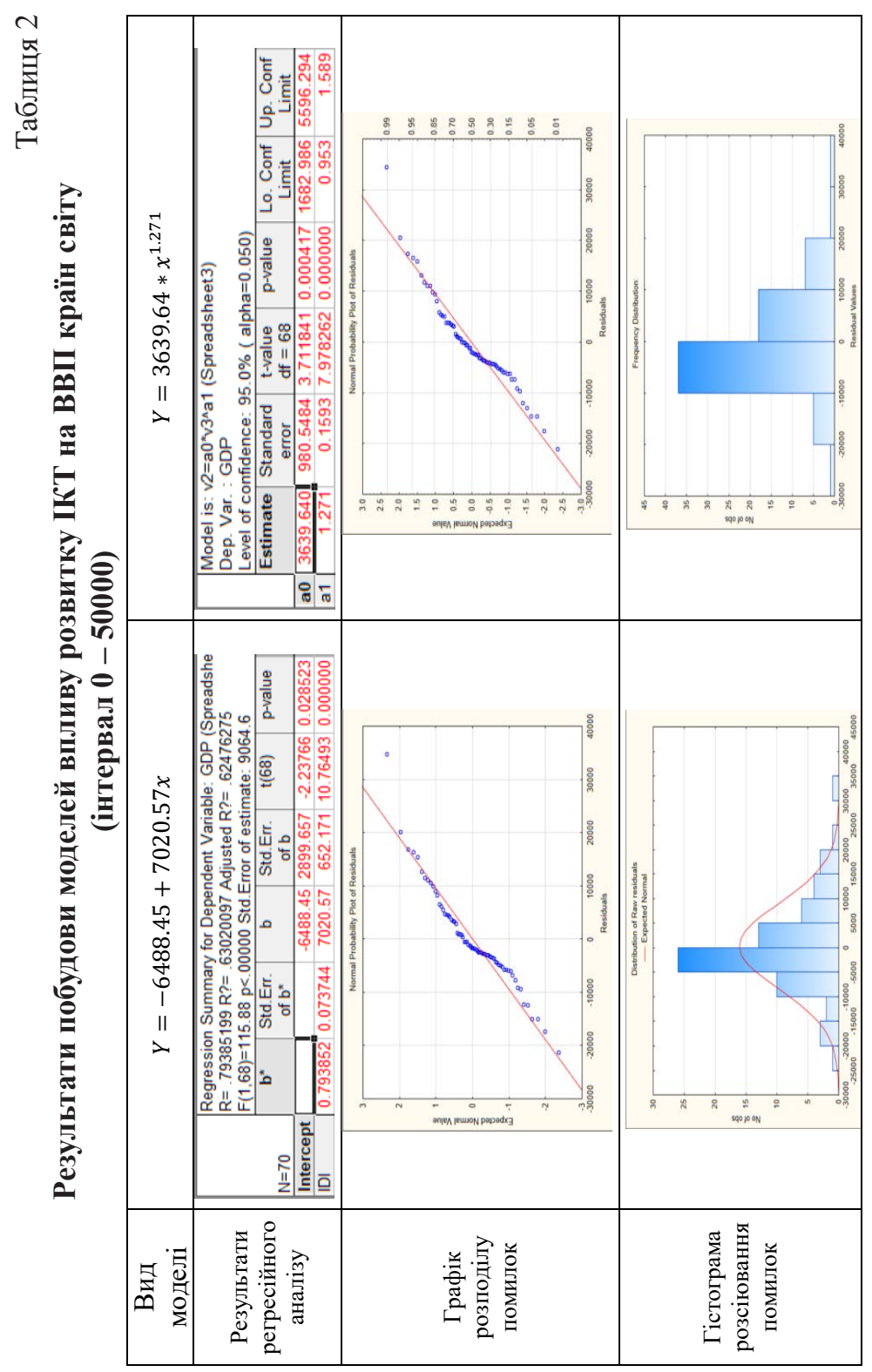

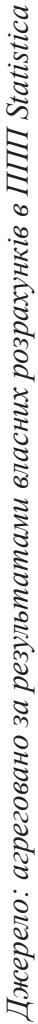


Спочатку оцінимо наявність лінійного зв'язку між змінними ВВП та індексом ІКТ для цього інтервалу (рядок 1 табл. 2). За результатами аналізу бачимо, що параметр при незалежній змінній статистично значущий та в цілому модель має високу прогностичну якість, оскільки коефіцієнт детермінації більше 0.6. Основні статистики та матриця коефіцієнтів парних кореляцій зображені у стовпці 3. Бачимо, що змінні мають високий ступінь кореляції (0.79). За допомогою графіку та гістограми розподілу помилок моделі (стовпці 4-5) перевіримо гіпотезу про нормальність розподілу похибок. У результаті порівняння видно, що розподіл помилок відповідає кривій нормального закону.

Перевіримо наявність нелінійного зв'язку (рядок 2 табл. 2). Степенева функція залежності ВВП від ІКТ наведена у стовпці 2, а результати оцінки параметрів моделі зображено у стовпці 3. Параметр при змінній статистично значущий, про що свідчить статистика Стьюдента. Результати дисперсійного аналізу підтверджують статистичну значущість моделі в цілому. Як бачимо з графіків у стовпцях 4-5, і гістограма і графік розподілу підтверджують гіпотезу про відповідність розподілу похибок моделі кривій нормального закону.

Результати побудови моделей для країн 3 другого інтервалу (50000 100000) наведені у таблиці 3. Спочатку оцінимо наявність лінійного зв'язку між змінними ВВП та індексом ІКТ для цього інтервалу. Результати регресійного аналізу представлено у рядку 1. Вигляд моделі наведено у стовпці 1, а основні статистики та матриця коефіцієнтів парних кореляцій зображені у стовпці 2. Ступінь кореляції між змінними середній - 0,523. Перевіримо гіпотезу про нормальність розподілу похибок за допомогою графіку та гістограми розподілу помилок моделі (стовпці 3-4). Бачимо, що розподіл помилок не відповідає кривій нормального закону.

Перевіримо наявність нелінійного зв'язку (рядок 2 табл. 3). Результати оцінки параметрів моделі зображено у стовпці 23. Результати дисперсійного аналізу підтверджують статистичну значущість моделі в цілому. Перевіримо чи відповідають помилки моделі нормальному закону розподілу похибок. Як бачимо, і гістограма і графік розподілу (стовпці 3-4) підтверджують гіпотезу про відповідність розподілу похибок моделі кривій нормального закону.

Результати побудови моделей для країн 3 третього інтервалу (100000 - 250000) наведені у таблиці 4. 


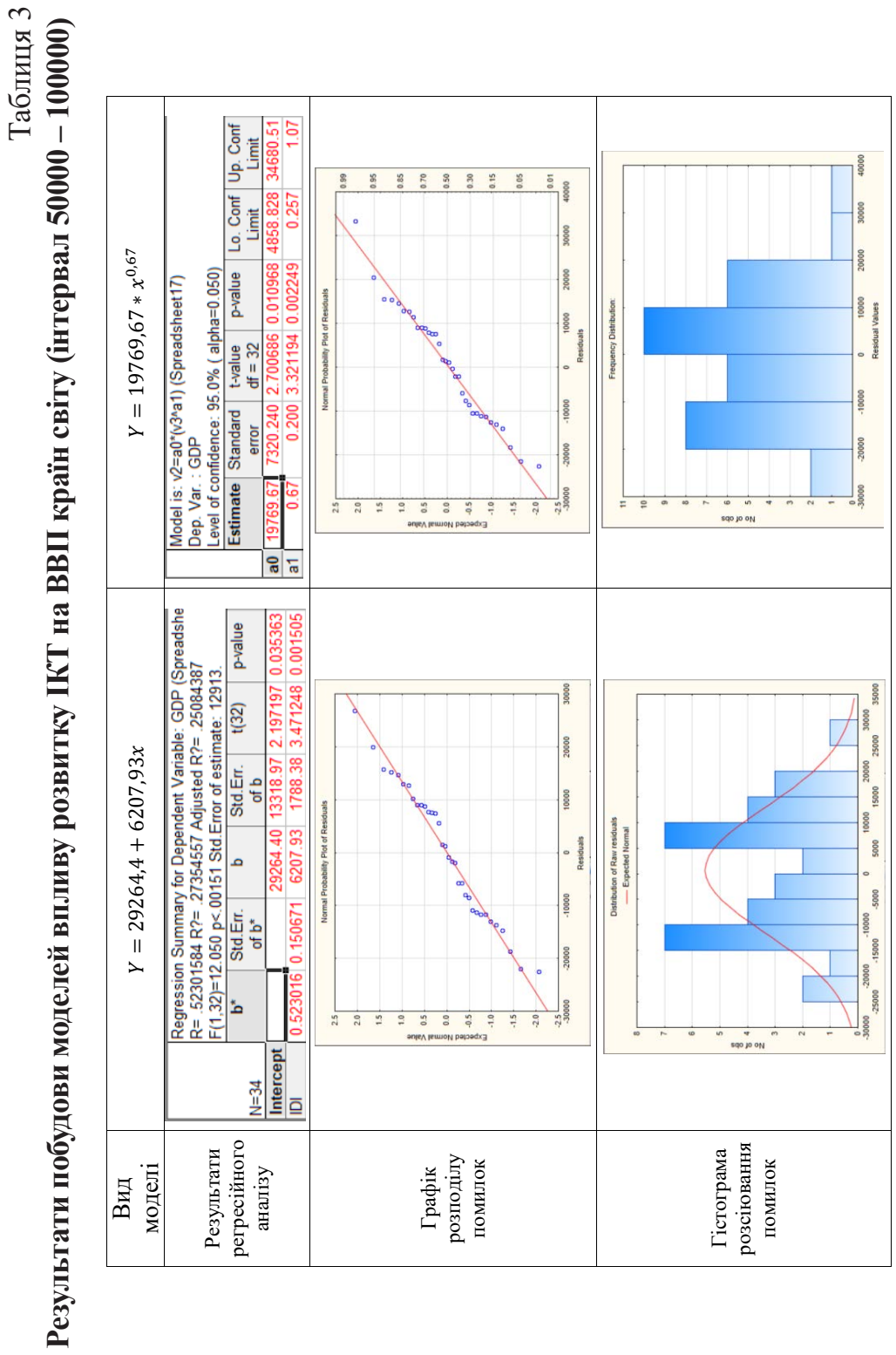

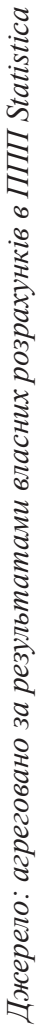


Chapter «Economic sciences»

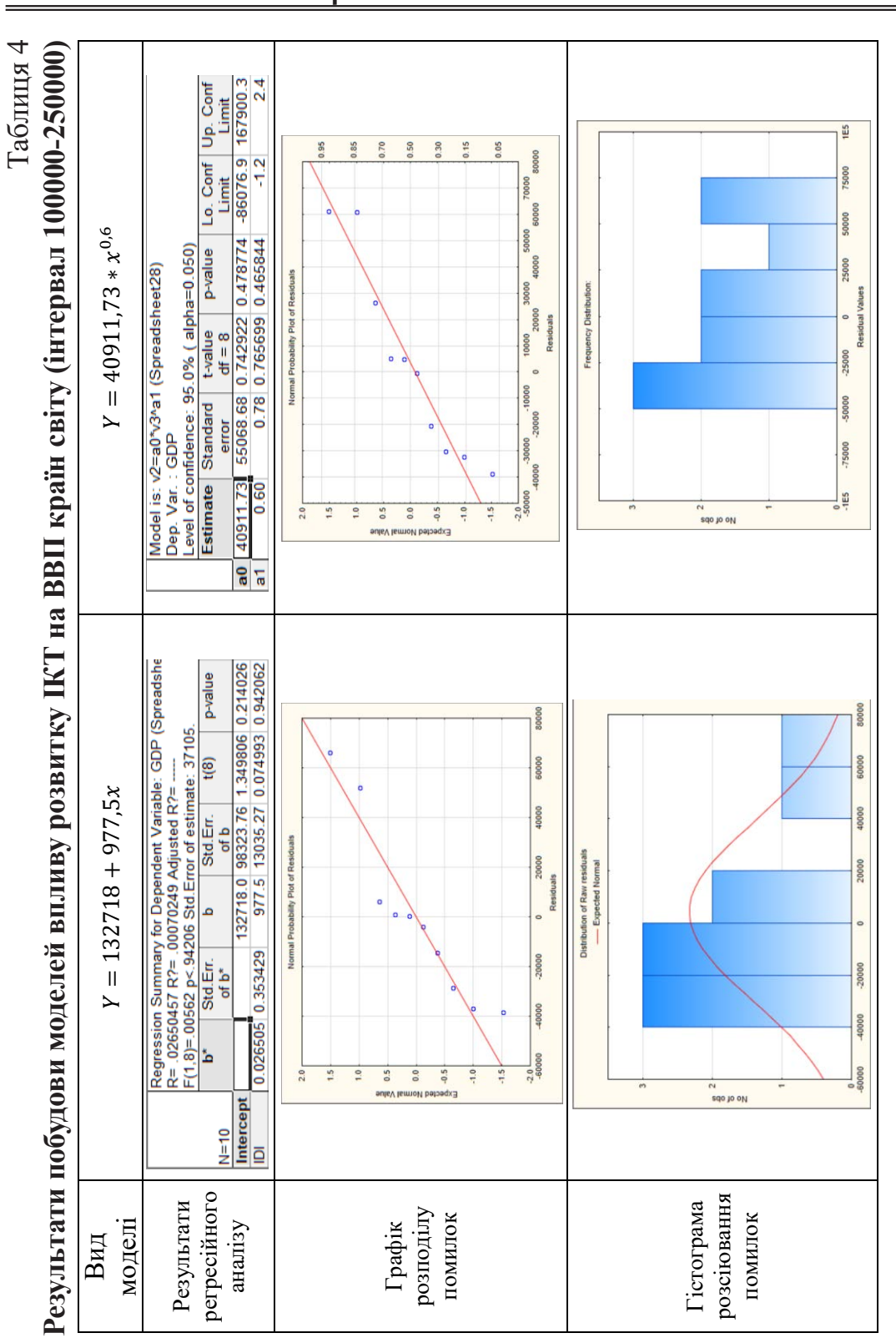

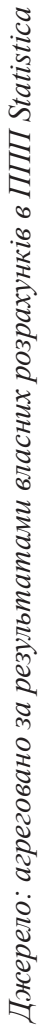


Спочатку оцінимо наявність лінійного зв'язку між змінними ВВП та індексом ІКТ ля цього інтервалу. Результати регресійного аналізу представлено у рядку 1. Рівняння моделі наведено у стовпці 1. Основні статистики та матриця коефіцієнтів парних кореляцій зображені у стовпці 2. Лінійний зв'язок між змінними є відсутнім, оскільки коефіцієнт кореляції дорівнює 0,0265. Перевіримо гіпотезу про нормальність розподілу похибок за допомогою графіку та гістограми розподілу помилок моделі (стовпці 3-4). Розподіл помилок не відповідає кривій нормального закону, що підтверджує відсутність лінійної залежності між досліджуваними показниками.

Спочатку оцінимо наявність лінійного зв'язку між змінними ВВП та індексом ІКТ ля цього інтервалу. Результати регресійного аналізу представлено у рядку 1. Рівняння моделі наведено у стовпці 1. Основні статистики та матриця коефіцієнтів парних кореляцій зображені у стовпці 2. Лінійний зв'язок між змінними є відсутнім, оскільки коефіцієнт кореляції дорівнює 0,0265. Перевіримо гіпотезу про нормальність розподілу похибок за допомогою графіку та гістограми розподілу помилок моделі (стовпці 3-4). Розподіл помилок не відповідає кривій нормального закону, що підтверджує відсутність лінійної залежності між досліджуваними показниками.

Перевіримо наявність нелінійного зв'язку. Результати регресійного аналізу представлено у рядку 2 табл. 4. Результати оцінки параметрів моделі зображено у стовпці 2. Результати дисперсійного аналізу підтверджують статистичну значущість моделі в цілому. Перевіримо чи відповідають помилки моделі нормальному закону розподілу похибок. Як бачимо з графіків у стовпцях 3-4, і гістограма, і графік розподілу підтверджують гіпотезу про відповідність розподілу похибок моделі кривій нормального закону.

Таким чином, здійснений аналіз дозволяе зробити висновки, що степенева функція краще описує залежність між показником ВВП та ІКТ як для усієї сукупності країн, так і за окремими групами. Параметр а1 в регресійній моделі відображає еластичність ІКТ відносно ВВП, тому дає змогу прогнозувати зміни ВВП країн та підтверджує твердження про необхідність розвивати інформаційно-комунікаційні технології та створювати умови для їх впровадження. 


\section{7. Висновки}

Розповсюдження інформаційних та телекомунікаційних технологій сприяє своєчасному і швидкому інформаційному обміну, що якісним чином покращує системи управління в світовому масштабі і впливає на конкурентоспроможність країн і національних ринкових суб'єктів. IКТ швидко поширюються в більшості країн, що розвиваються - насамперед мобільна телефонія, але також і комп’ютери, і Інтернет. Впровадження IКТ породжує мультиплікативні ефекти, змінюючи якість життя, практику ведення бізнесу, функціонування державних установ. ІКТ - новий ресурс розвитку, що висуває підвищені вимоги до якості державних інститутів і освітніх систем. Інформатизація прямо або побічно сприяє вирішенню багатьох актуальних проблем бідних країн - таких, як низька грамотність, висока народжуваність, нерівноправність жінок, недостатній рівень заощаджень, бюрократизм держустанов, низька якість життя. В сучасних умовах конкурентоспроможність країни визначається ступенем та якістю застосування ІКТ. Одним з головних факторів гарної діяльності підприємства $є$ його спроможність адаптуватись до змінних умов зовнішньої середи його функціонування. Таку ж вимогу можна висунути і до держави в цілому. Спроможність адаптуватись, приймати та прагнути до світових стандартів, які задають розвинені країні, одна 3 головних умов для процвітання країни. Сучасний ритм життя вимагає інформатизації у всіх її проявах, і розроблені моделі ще раз це підтверджують. Як бачимо, зв'язок між ІКТ та об'ємами ВВП існує. При чому результати дослідження виявились такими, що потенціал для нарощування ВВП через ІКТ більше для країн, що розвиваються ніж для розвинених. Можливо це пов'язано з тим, що для розвинених країн практика використання IКТ вже давно не розкіш, а звичайна повсякденність. На мою думку має місце явище перенасичення. Ефект від подальшого розвитку ІКТ в розвинених країнах такий, що при збільшенні об'ємів використання ІКТ на 1\% ВВП збільшується на 0.6\%. При чому показники індексу розвитку в цих країнах зараз дуже високі і позиції цих країн в світовому рейтингу з року і рік кардинально не змінюються. Залежність між ВВП та ІКТ вже давно відома. Саме тому досліджується так багато індексів інформаційного суспільства, публікуються річні звіти про рівні використання інформаційних технологій в країнах. Тобто, зараз використання IКТ розвиненими країнами - необхідність для збереження та 
покращення існуючих показників в сучасних ринкових умовах. В той же час для країн, що розвиваються ситуація протилежна. Збільшення IКТ на $1 \%$ призводить до збільшення об'ємів ВВП на $1.2 \%$ в середньому. Тобто, у таких країн $є$ потенціал для розвитку, для досягнення показників розвинутих країн.

\section{Список літератури:}

1. Голяндина Н. Э. Метод «Гусеница»-SSA: прогноз временных рядов : Учеб. пособие. СПб : Изд-во СПбГУ, 2004. 52 с.

2. Гурьянова Л. С., Клебанова Т. С., Кавун С. В. Инновационные и информационные технологии в развитии национальной экономики: теория и практика. Раздел. Инновационно ориентированные модели сбалансированного развития регионов / Под ред. Т. С. Клебановой, В. П. Невежина, Е. И. Шохина. Москва : Научные технологии, 2013. С. 173-182

3. Державна служба статистики. URL: http://www.ukrstat.gov.ua/

4. ПРАКТИКУМ [Р.100] Ассоциативные правила в Deductor Studio. URL: https://docplayer.ru/28624136-Praktikum-p-100-associativnye-pravila-v-deductorstudio.html

5. Сайт Всесвітнього Банку. URL: http://data.worldbank.org/

6. Черняк О. І., Ставицький А. В. Динамічна економетрика : Навчальний посібник. Київ : КВІЦ, 2000. 120 с.

7. Chen S. Characteristics and development of information industry and its impact on the economy / S. Chen // Springer Science + Business Media Singapore. 2016. $499 \mathrm{p}$.

8. EconStats. URL: http://www.econstats.com/wdi/wdic_UKR.htm

9. European Innovation Scoreboard 2020. URL: https://interactivetool.eu/EIS/ EIS 2.html

10. Gauging ICT potential around the world. ITU releases the first global Digital Access Index 10/2003

11. Internet World Stat. Usage and population statistics. URL: http://www.internetworldstats.com/

12. ITU, Measuring the Information Society Report 2019. URL: http://www.itu.int/en/ITU-D/Statistics/Documents/publications/mis2014/ MIS2019_without_Annex_4.pdf

13. Measuring the Information Society Report 2008, 2011, 2014, 2017, 2019. URL: https://www.itu.int

14. Net Index Explorer. URL: http://explorer.netindex.com/

15. OECD, 1986, Trends in The Information Economy (Paris).

16. Porat, Marc U and Rubin, Michael R. 1977. The Information Economy (9 volumes). Office of Telecommunications Special Publication 77-12 (US Department of Commerce, Washington D. C.).

17. Porat, Marc U., U. S. Dep't Of Commerce, OT Special Pub. 77-12(1). The Information Economy: Definition And Measurement. Vols. 1-8 (1977). 
18. Trevor Hastie, Robert Tibshirani, Jerome Friedman. Chapter 14.4 SelfOrganizing Maps // The Elements of Statistical Learning. 2009. P. 528-534.

\section{References:}

1. Golyandina N. E. (2004) Metod «Gusenica»-SSA: prognoz vremennyh ryadov: Ucheb. posobie. SPb: Izd-vo SPbGU, $52 \mathrm{p}$.

2. Gur'yanova L. S., Klebanova T. S., Kavun S. V. (2013) Innovacionnye i informacionnye tekhnologii v razvitii nacional'noj ekonomiki: teoriya i praktika. Razdel. Innovacionno orientirovannye modeli sbalansirovannogo razvitiya regionov / Pod red. T. S. Klebanovoj, V. P. Nevezhina, E. I. SHohina. Moscow: Nauchnye tekhnologii, pp. 173-182.

3. Derzhavna sluzhba statistiki. URL: http://www.ukrstat.gov.ua

4.PRAKTIKUM [P.100] Associativnye pravila v Deductor Studio. URL: https://docplayer.ru/28624136-Praktikum-p-100-associativnye-pravila-v-deductor-studio.html

5. Sajt Vsemirnogo Banka. URL: http://data.worldbank.org/

6. Chernyak O. I., Stavitskiy A. V. (2000) DinamIchna ekonometrika: Navchalniy posIbnik. Kyiv: KVITs, 120 p.

7. Chen S. (2016) Characteristics and development of information industry and its impact on the economy / Springer Science + Business Media Singapore, 499 p.

8. EconStats. URL: http://www.econstats.com/wdi/wdic_UKR.htm

9. European Innovation Scoreboard 2020. URL: https://interactivetool.eu/EIS/ EIS 2.html

10. Gauging ICT potential around the world. ITU releases the first global Digital Access Index 10/2003

11. Internet World Stat. Usage and population statistics. URL: http://www.internetworldstats.com/

12. ITU, Measuring the Information Society Report 2019. URL: http://www.itu.int/en/ITU-D/Statistics/Documents/publications/mis2014/ MIS2019_without_Annex_4.pdf

13. Measuring the Information Society Report 2008, 2011, 2014, 2017, 2019. URL: https://www.itu.int

14. Net Index Explorer. URL: http://explorer.netindex.com/

15. OECD, 1986, Trends in The Information Economy (Paris).

16. Porat, Marc U and Rubin, Michael R. (1977) The Information Economy (9 volumes), Office of Telecommunications Special Publication 77-12 (US Department of Commerce, Washington D. C.).

17. Porat, Marc U., U. S. Dep't Of Commerce, OT Special Pub. 77-12(1). The Information Economy: Definition And Measurement, vols. 1-8 (1977).

18. Trevor Hastie, Robert Tibshirani, Jerome Friedman. Chapter 14.4 SelfOrganizing Maps // The Elements of Statistical Learning, 2009, pp. 528-534. 